\title{
The relationship between landslide activity and weather: examples from Hungary
}

\author{
J. Szabó \\ Department of Physical Geography, P.O. Box 9, H-4010 Debrecen, Hungary \\ Received: 27 November 2001 - Revised: 7 May 2002 - Accepted: 8 May 2002
}

\begin{abstract}
The paper presents the impact of irregular rainfall events triggering landslides in the regional context of landslides in Hungary. The author's experience, gathered from decades of observations, confirms that landslide processes are strongly correlate with precipitation events in all three landscape types (hill regions of unconsolidated sediments; high bluffs along river banks and lake shores; mountains of Tertiary stratovolcanoes). Case studies for each landscape type underline that new landslides are triggered and old ones are reactivated by extreme winter precipitation events. This assertion is valid mainly for shallow and translational slides. Wet autumns favour landsliding, while the triggering influence of intense summer rainfalls is of a subordinate nature. A recent increasing problem lies in the fact that on previously unstable slopes, stabilised during longer dry intervals, an intensive cultivation starts, thus increasing the damage caused by movements during relatively infrequent wet winters.
\end{abstract}

\section{Introduction}

One of the most frequent causes of landsliding is the decreased stability of slope material, related particularly in the case of unconsolidated sediments to a sudden change in water content. In general, the moisture content of slopes depends mainly on climate, and in particular on weather conditions. The latter explains primarily why landsliding is discontinuous in time and space, even where conditions are favourable. The discontinuity in time may be related to climatic change on a large scale (e.g. an arid climate becomes more humid), to the seasonal humidity of the climate in the medium term (e.g. movements are more common in wet seasons) and to climatic extreme events in the short term (e.g. unexpectedly abundant precipitation). However, this regularity, which may be regarded as general, is manifested in different forms in various physical landscape types. As a consequence, the contribution of slides and the features created

Correspondence to: J. Szabó (wagner@ tigris.klte.hu) by them may be largely variable in the geomorphic evolution of regions where conditions are favourable. Rock quality, stratification, slopes with high variability locally (e.g. as a result of lateral river erosion) lead to various landslide types, and the changing weather conditions affect them in different ways.

The paper investigates some aspects of the relationship between landslides and weather in the regional context of landslides in Hungary (Szabó, 1992, 1993, 1996a). In addition, the author introduces some case studies, particularly from the northeastern part of the country.

\section{Methods}

The author has been investigating landslides and the features produced by them for more than thirty years. Research has been focused primarily on the northeastern part of Hungary, where projects of detailed geomorphological mapping have been carried out for several hill regions. Field experience covers all regions of Hungary affected by landsliding. Following a range of partial reports, in 1996, a comprehensive evaluation was prepared on the contribution of landsliding to the geomorphic evolution of Hungarian landscapes (Szabó, 1996a). This paper exploits previous experience supplemented with additional data on rainfall and analyses of the conditions of some new or reactivated landslides (e.g. at Hollóhàza), in order to point out typical features in the precipitation/landslide relationship.

\subsection{Regional distribution of landslides in Hungary}

More than two-thirds of the area of Hungary, occupying the central part of the Carpathian Basin, is lowlands, but landslides occur in 107 (47\%) of the 230 physical microregions conventionally identified (Szabó, 1996b). This is explained by the fact that the landscape pattern of areas of higher relief and dissection is finer (usually smaller microregions are delimited) and unconsolidated sediments predominate. 
Table 1. Regional distribution of landslides in Hungary. Nomenclature after Hansen (1984), Simonett (1968), Hutchinson (1968)

\begin{tabular}{|c|c|c|c|c|c|}
\hline Landscape types & $\begin{array}{c}\text { Characteristic } \\
\text { material } \\
\text { of slip plane }\end{array}$ & $\begin{array}{c}\text { Typical } \\
\text { position } \\
\text { of slip plane }\end{array}$ & $\begin{array}{l}\text { Morphological } \\
\text { position of } \\
\text { slide }\end{array}$ & $\begin{array}{l}\text { Typical } \\
\text { forms }\end{array}$ & \\
\hline \multirow{3}{*}{$\begin{array}{l}\text { Hill } \\
\text { regions }\end{array}$} & \multirow[t]{2}{*}{ Transdanubia } & $\begin{array}{c}\text { - surface of } \\
\text { Pannonian layers }\end{array}$ & $\begin{array}{c}\text { deep seated } \\
\text { (near base level) }\end{array}$ & $\begin{array}{c}\text { - tectonic } \\
\text { margin of landscapes }\end{array}$ & \multirow[t]{2}{*}{$\begin{array}{c}\text { Earth } \\
\text { block slides }\end{array}$} \\
\hline & & $\begin{array}{c}\text { - loam zones } \\
\text { in loess }\end{array}$ & & $\begin{array}{c}\text { - valley } \\
\text { slopes }\end{array}$ & \\
\hline & $\begin{array}{l}\text { Northern } \\
\text { Hungary }\end{array}$ & $\begin{array}{c}\text { - various } \\
\text { Pannonian layers } \\
\text { - surface of } \\
\text { Pannonian layers }\end{array}$ & $\begin{array}{c}\text { shallow } \\
\text { (above base level) }\end{array}$ & $\begin{array}{l}\text {-valley } \\
\text { slopes }\end{array}$ & $\begin{array}{c}\text { Earth } \\
\text { block slides, } \\
\text { often } \\
\text { mudslides, } \\
\text { slabslides }\end{array}$ \\
\hline \multirow{3}{*}{ Bluffs } & & & - near base level & \multirow{3}{*}{$\begin{array}{l}\text { margin } \\
\text { of } \\
\text { bluffs }\end{array}$} & \multirow{3}{*}{$\begin{array}{c}\text { planar } \\
\text { block glides } \\
\text { Earth } \\
\text { block slides }\end{array}$} \\
\hline & Danube & $\begin{array}{l}\text { as in } \\
\text { Transdanubia }\end{array}$ & - on base level & & \\
\hline & Hernád & $\begin{array}{l}\text { various } \\
\text { Pannonian } \\
\text { layers }\end{array}$ & $\begin{array}{l}\text { - above base level } \\
\text { - on base level }\end{array}$ & & \\
\hline \multirow[b]{2}{*}{$\begin{array}{l}\text { Volcanic } \\
\text { mountains }\end{array}$} & & $\begin{array}{l}\text { - loose base of } \\
\text { volcanic rocks }\end{array}$ & & $\begin{array}{l}\text { - edge of } \\
\text { volcanoes }\end{array}$ & $\begin{array}{l}\text { rock slides, } \\
\text { block glides }\end{array}$ \\
\hline & & $\begin{array}{l}\text { - weathered } \\
\text { tuffs }\end{array}$ & $\begin{array}{c}\text { deep seated } \\
\text { (near base level) }\end{array}$ & $\begin{array}{l}\text { - steep margin } \\
\text { of calderas } \\
\text {-slopes of deep } \\
\text { inner valleys }\end{array}$ & $\begin{array}{c}\text { rarely } \\
\text { rock slumps }\end{array}$ \\
\hline
\end{tabular}

There are three landscape types in Hungary where past or present geomorphic evolution has been significantly influenced by landsliding, and landslides are major features in the landscape. This primarily refers to landslides of a natural origin, but with the expansion of intensive land use types; man-induced landslides have also been reported as a considerable hazard.

The distribution of areas with a high landslide density (more than 1 landslide per $1 \mathrm{~km}^{2}$ ) or with a high landslide hazard is shown in Fig. 1, whereas Table 1 provides a comprehensive description of landslide-affected landscape types.

- A Hills built up of Tertiary (mainly Neogene) sediments

Hills in southern Transdanubia. The low stability slopes are typically built up of Upper Miocene (Pannonian) marine-lacustrine loams and sands with a thick $(20-40 \mathrm{~m})$ loess mantle. Since the stability of loess is relatively higher than the Pannonian sediments, sliding is concentrated mainly on slopes of deeply incised valleys, exposing Pannonian deposits under loess. Such landslides are usually deep-seated and their slip planes are located under the loess in the Pannonian sediments. As a consequence, the large moisture content causing landslides is not directly related to precipitation (the wa- ter does not infiltrate through the thick loess layer), but indirectly through groundwater flow.

Hilly regions in the North Hungarian Mountains. The majority of the natural landslides occur in the area of Pannonian sediments. These deposits present the lowest stability in Hungary. They are not usually covered by loess but by a Plio-Pleistocene veneer of equally low stability. Consequently, shallow slip planes are formed mostly below the base level. The surface extension of landslides is usually remarkable but their thickness is small. The D/L ratio of Skempton (Crozier, 1973) is only a few percent. Therefore, landslides are more directly linked to precipitation. (In hill regions made up of older - Oligocene and Lower-Middle Miocene - sediments, landslides of natural origin are less common.)

- B Landslides along bluffs

Landsliding is a common phenomenon along the River Danube (south of Budapest) and along the high bluffs around Lake Balaton, as described in the literature (Pécsi et al., 1993; Lóczy et al., 1989; Pécsi, 1994; Juhász and Schweitzer, 1989; Juhász, 1999). The landslides along the southern shore of Ferto Lake, the right bank of Rába River and the movements of the bluffs of 


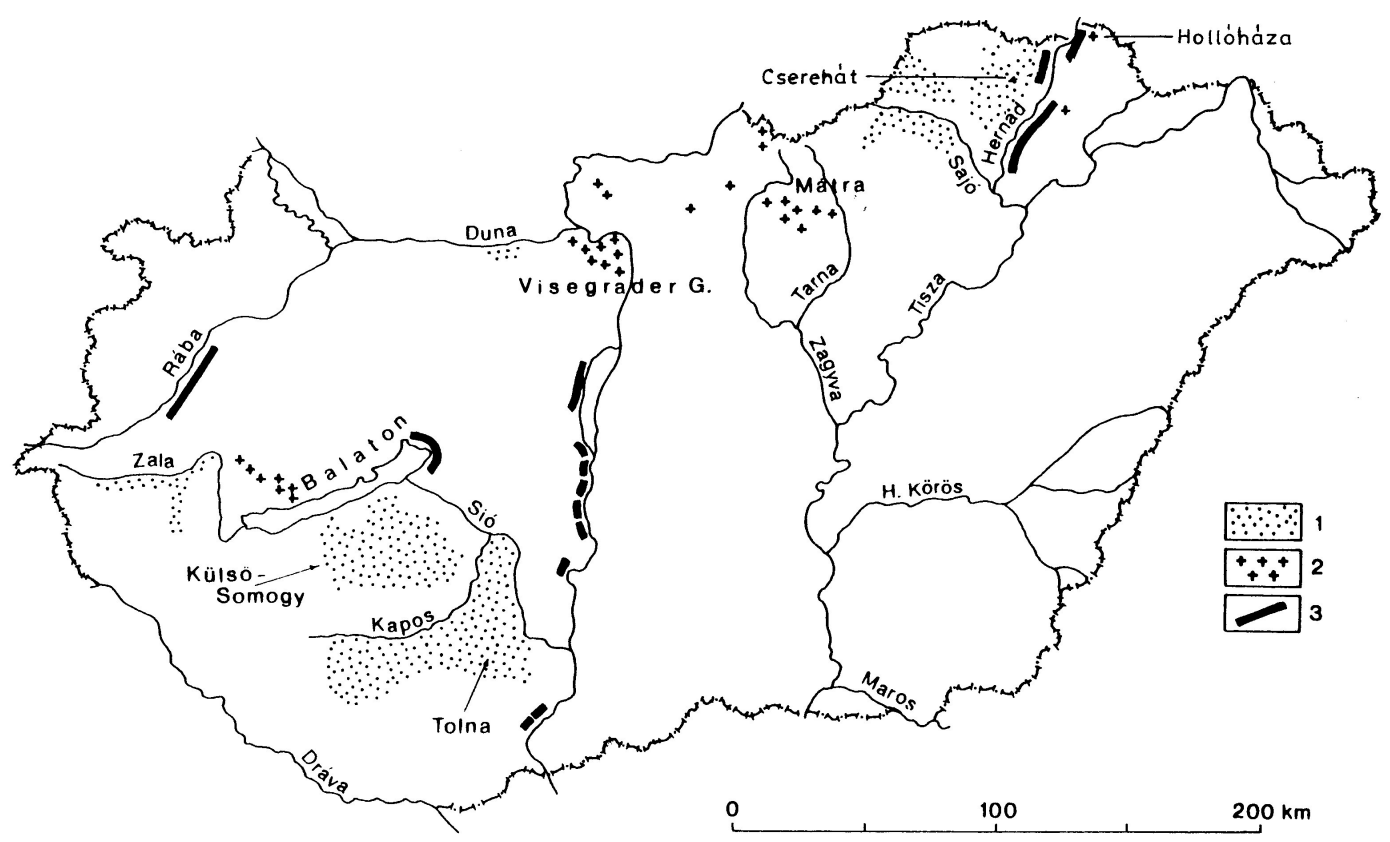

Fig. 1. Regions affected by high landslide density in Hungary. $1=$ hill regions with landslides, $2=$ buff zones with landslides, and $3=$ mountains of volcanic origin with landslides.

Hernád River are less studied - although the latter is the most active landslide zone in Hungary. A common characteristic of mass movements of the regions, geographically distant from each other, is that in the majority of the cases, the bluffs are built up of Pannonian deposits (Table 1). The cover deposits of Pannonian sediments are variable for type and thickness. This variability significantly influences the nature and location of the slip planes and the features of landslides.

- C Landslides in mountains of volcanic origin.

The landslide features of Hungarian mountains of volcanic origin present a different lithological environment. The volcanoes were active in the middle and late Miocene. Their lava and pyroclastic products (with a strato-volcano structure) accumulated on Neogene sediments. The landslides of the volcanic mountains developed in three distinct geomorphological situations:

a) along the edge of volcanoes, where unconsolidated bedrock is exposed on the surface and these sediments of low stability form the slip plane for the sliding volcanic rock masses. Such a stratification occurs frequently and typical sliding zones have been reported along the mountain margins;

b) within the mountains, on the steep margins of former calderas;

c) on the slopes of deep valleys dividing the mountains, where a valley incision reached the rocks underlying the volcanic products.

Sometimes slip planes of landslides also appear within the strato-volcanic structure. Particularly heavily decomposed tuff layers form sliding surfaces. Landslide hazard is especially high if these impermeable or weak weathered tuff aquifers are wedged in between agglomerate masses of high water permeability. The landslides in mountains areas are usually deep-seated (sometimes $100 \mathrm{~m}$ deep).

\subsection{Climatic and meteorological aspects of landslides}

In the three landscape types described above, the preconditions for landslides are rather different and this variation is also reflected by the mechanisms, activity and morphology of landslides.

Where eroded fossil features are widespread but active slides are missing, major climatic changes must have caused landsliding to stop. Generally, this is the case in mountains of volcanic origin (e.g. in the Mátra and Visegrád Mountains). In the moors of hollows impounded by landslides, chronological data (Szabó and Félegyházi, 1997) have been obtained to demonstrate that these movements in the mountains were at a rest during most of the Holocene. Their formation may be most probably dated to the beginning of the Holocene, or the warming climatic periods of the Late Glacial and Preboreal phases. The relative intact forms are due to large size and the hard volcanic rocks. There are no similar old features in the hill regions or along the high bluffs, since unconsolidated deposits do not favour their preservation. Thus, deep seated, large-scale rockslides do not constitute a real hazard under the present climatic conditions. In several volcanic mountains in Hungary, their zonally arranged remnants attest to a climatic phase when periglacial conditions ceased to exist and humid environments suitable for large-scale landslides prevailed. 
Table 2. Annual and winter mean precipitation ( $\mathrm{mm}$ ) in Cserehát and in various hill regions of Transdanubia (based on data of representative stations: 1901-1975)

\begin{tabular}{ccccc}
\hline $\begin{array}{c}\text { Landscape } \\
\text { (Station) }\end{array}$ & $\begin{array}{c}\text { Cserehát } \\
\text { (Abod }-228 \mathrm{~m} \\
\text { above sea level) }\end{array}$ & $\begin{array}{c}\text { Outer Somogy } \\
\text { (Tab }-177 \mathrm{~m} \\
\text { a.s.l.) }\end{array}$ & $\begin{array}{c}\text { Zselic Hills } \\
\text { (Bôszénfa }-172 \mathrm{~m} \\
\text { a.s.1.) }\end{array}$ & $\begin{array}{c}\text { Zala Hills } \\
\text { (Zalalövő - 191 m } \\
\text { a.s.l.) }\end{array}$ \\
\hline Year & 595 & 667 & 713 & 800 \\
Winter (XII-II) & 96 & 124 & 135 & 133 \\
\hline
\end{tabular}

The present-day climate does not allow for the occurrence of landslides of large dimension to seem probable, but there are still recent - or even active - landslides in the volcanic mountains. They are most often found in valleys and valley basins, where decomposed tuffs and other unconsolidated often marine - sediments are abundant near the surface. The main triggering factor is usually human activity (e.g. road cuts, construction of buildings) that modifies the shape, the loading of the slopes and the moisture conditions (changing the surface water budget, lack of public utilities, etc.). They usually occur irregularly after longer periods of tranquillity which highly increases their hazards. The periods of tranquillity decreases the focused attention of the population and construction work takes place on the potentially unstable slopes during decade-long breaks between landsliding events.

This is even more typical for landslides in hill regions and along bluffs. The reactivation of landslides may be related to the irregular precipitation distribution under continental climate, to years of wet weather and even more characteristically to heavy rainfall in extreme weather situations. Particularly for shallow landslides, exceptionally high precipitation and the reactivation of landslides are strongly correlated. Relatively precise correlation can be revealed since the beginning of regular precipitation measurements (in Hungary mostly until the early 20th century). More correlation can be verified up to a few decades, which is within the range of existing human memory about landslides. During the author's own landslide investigations of the past three decades, direct evidence was gathered to confirm the above relationships.

\section{Case studies}

\subsection{Hill regions (Cserehát)}

\subsubsection{Lithology and relief}

In the northernmost hill region of the country, the Cserehát (Fig. 2), between Bódva and Hernád Rivers, valleys are cut into Pannonian lacustrine-marine loams and sands sediments except for the western margins, entirely dissecting the Pliocene pediment (glacis) surface. Today, its remnants are only detectable in narrow interfluvial ridges, although this is still the landscape with the lowest valley density among all Hungarian hill regions. The primary reason for low valley density is the low stability of Pannonian sediments. Intense mass movements occurred during the Pleistocene and broadened the valleys. Among them, landsliding played the main role.

\subsubsection{Landsliding and precipitation}

Similar processes also operate under the present climate, although the hill region has a low precipitation, especially compared to the Trans-danubian Hills of humid climate. Winter precipitation, an important factor in triggering landslides, is particularly low (Table 2). Given these conditions, it is expected that landslide activity increases mainly after wet winters with abundant snowfall.

In the spring of 1977, the largest number of new or reactivated landslides was recorded during the thirty years of observation (Fig. 2). The winter of 1976/1977 was especially wet. At one of the measurement stations included in Table 2 (Abod), total precipitation of the winter months was $247 \mathrm{~mm}, 257 \%$ of the 75 -year average. Similar ratios were obtained for other stations in the Cserehát region: Gagybátor, 266\%; Szikszó, 262\%. Higher winter precipitation in Hungary was measured only once: in the winter of 1914/1915 (in Szikszó the precipitation was $348 \%$ and in Gagybátor it was $287 \%$ of the average of 75 years). In the case of the reactivated landslides - with a single exception - slip planes were near the surface (at $<3 \mathrm{~m}$ depth). Consequently, soils and near-surface sediments became saturated by the end of the winter, creating ideal conditions for shallow ("carpet-like") landslides. Fortunately, the renewed landslides did not affect settlements, and their damage was restricted to agricultural land. In the author's opinion, intensive summer precipitation usually induces considerable soil erosion on the Cserehát Hills, almost exclusively used for agricultural purposes. The landslide-generating impact of summer rains, however, is minimal. The landslides are usually related to winter precipitation.

\subsection{High bluffs along the Hernád River}

\subsubsection{Rocks and topography}

Along the southern section of the Hernád valley, the zone of $70-80 \mathrm{~m}$ high bluffs is almost $30 \mathrm{~km}$ long and $500-1000 \mathrm{~m}$ wide (Figs. 1 and 4). Landslides are major features in this zone. In the bluff, almost exclusively Pannonian deposits, al- 


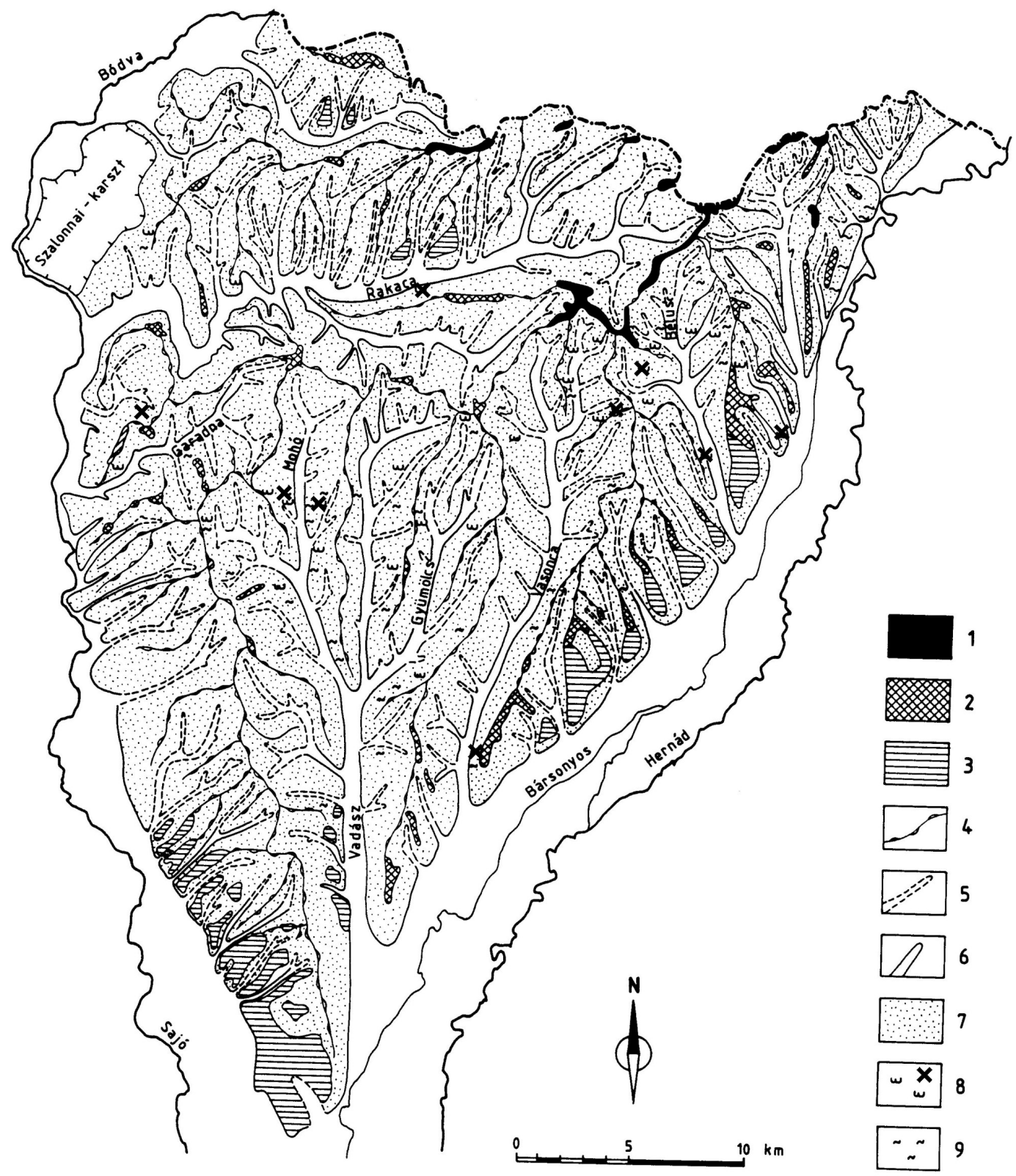

Fig. 2. Geomorphologic map of the Cserehát Hills. 1 = glacis remnants with gravels (*300 m .a.s.1.) - Upper Pliocene, $2=$ broad interfluvial ridges (280-300 m a.s.l.), $3=$ river terrace and valley-glacis (Pleistocene), $4=$ narrow interfluvial ridges, $5=$ derasional (dry) valley, $6=$ fluvial valley, 7 = slopes, $8=$ active landslides (black crosses show new and reactivated landslides in spring 1977), $9=$ temporarily dormant and stabilised landslides. White areas indicate valley floors.

ternating beds of sands and clays-silts, are exposed and only mantled by $(<5 \mathrm{~m}$ thick) loess. Although the bluff susceptible to landsliding is formed and maintained by lateral erosion, the majority of the landslides here are not directly controlled by the water level of the river.

In contrast, researchers (Horváth and Scheuer, 1976) have pointed out that along the Danube, most of the landslides take place during the steep falling limbs of flood hydrographs. It is explained by the locations of slip planes (bedding planes of Pannonian deposits) which are around the average water level of the Danube at many places. At a high water level, river water flows between beds decreases their stability. At the same time, the water also functions as a support. The supporting effect, however, ceases during the period of the rapidly dropping water levels.

\subsubsection{Landsliding and precipitation}

The slip planes of the landslides along the Hernád River may be more deeply seated than in the Cserehát (ca. 5-10 m or even more). They are considerably higher than the highest water level of the river. The water supply inducing landslides results primarily from the confined groundwater flow- 
ing from the inner areas. In some cases, the water infiltrates at the top of the bluffs already affected by sliding.

The author's research showed that the irregular recurrence of landslides may be explained fundamentally by the fluctuation in precipitation. Winter precipitation is of particular significance. This conclusion is drawn from the results of the questionnaire survey performed in 6 settlements of the riparian zone (land owners were asked about the dates of movements affecting their properties) and from the data of the State Insurance Company. These data sets have been compared with the precipitation time series for 75 years (Fig. 3).

Attention should be directed to the processes in the midseventies. Although no direct observations could be made, local data indicate that disastrous landslides occurred during the springs of 1975 and 1977. Data received from the State Insurance Company show that large sums of compensation (approximately USD 25000 at contemporary price) were paid in 3 villages in the high bluff zone (Felsödobsza, Hernádkércs, Szentistvánbaksa). In Hernádkércs, 13 houses of the part of the settlement built on the bluff were evacuated. This part of the settlement was finally abandoned by the inhabitants. It is worth mentioning that in the poor villages of the Hernád valley, property insurance is still an exception. Consequently, the rate of damage could be an order of magnitude higher than indicated - not to mention the damage made to the gardens along the bluffs.

The winter of 1974/1975 was not really wet but the October of 1974 was the wettest October in the 20th century (at Gibárt $172 \mathrm{~mm}$ fell - 4.1 times more than during the 19011970 period) and led to landsliding in the next spring. The winter of 1976/1977, similar to the Cserehát Hills, was also exceptionally humid in the Hernád Valley (Table 3).

A band chart was prepared for the $20 \mathrm{~km}$ long segment of the Hernád Bluff (Fig. 4). This indicates grades for the general activity of each slope section, with special emphasis on those areas where there were landslides resumed or new movements occurred in 1975-1977.

\subsection{Mountains of volcanic origin (Hollóháza - 1999)}

\subsubsection{Rocks and topography}

Hollóháza, the northernmost settlement in Hungary (Fig. 1), is situated in a valley crossing a strongly eroded Miocene volcanic caldera at $280-520 \mathrm{~m}$ above sea level. Here, "rhyolite tuff and loamy marine sediments of various thickness are superimposed on the underlying andesite" (Zelenka and Trauer, 1999). Their layers dip towards the valley, conducting water in that direction. Another important feature is that bentonitic rhyolite tuff, as well as clays, show an extremely high montmorillonite content (40-50\%). The upper part of the alternating tuff and clay beds of high swelling capacity lean mainly against the steep slopes of the mountains built up of lava rock. Most of the water discharge comes along a plane dissecting the surface.

There had been landslides on the slopes over the village even before. Their temporarily stabilised forms may be seen

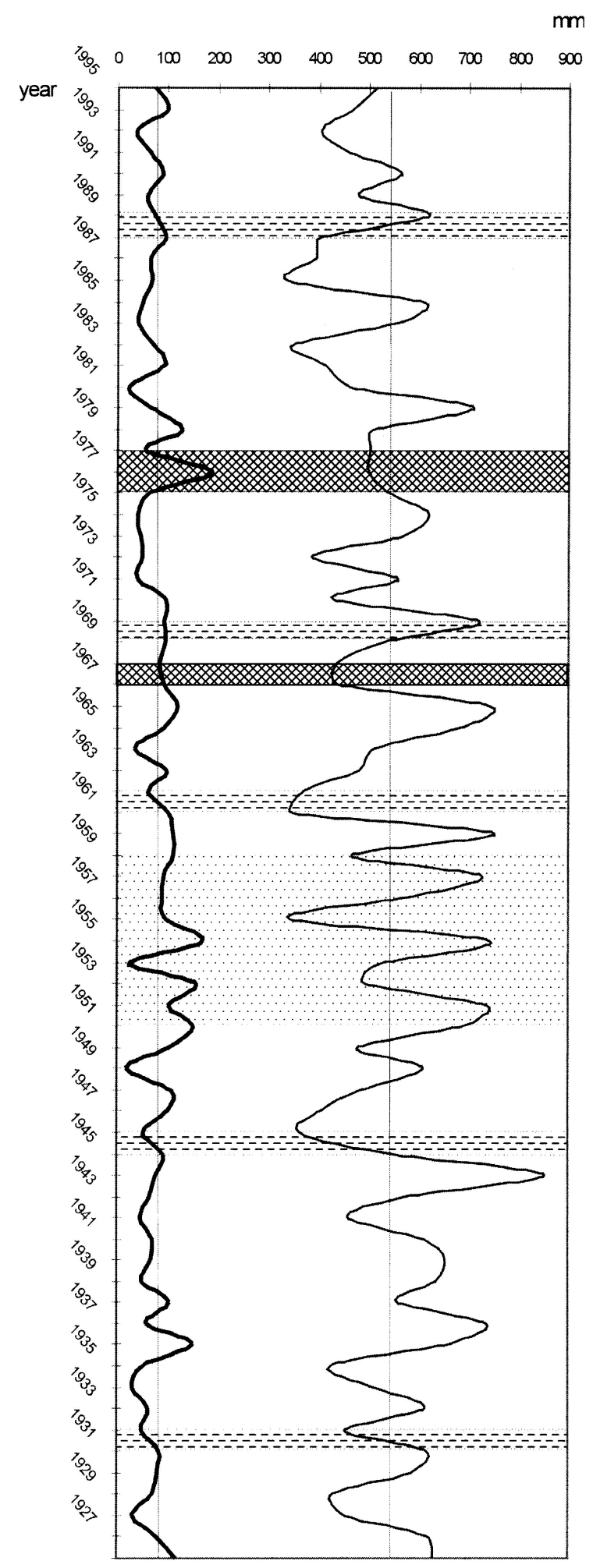

Fig. 3. Relationship between precipitation and landslide phases in the Hernád Valley. Thick line $=$ winter precipitation, thin line $=$ annual precipitation. Dotted stripe $=$ indistinctly defined landslide phase, broken line $=$ distinctly defined landslide phase, dark stripe = interval with intensive landsliding. 
Table 3. Precipitation during the winter 1976/1977 and mean winter precipitation 1901-1975 in mm. (Hernád Valley)

\begin{tabular}{cccccccccc}
\hline Station & \multicolumn{3}{c}{ Winter 1976/1977 } & Total 1 & \multicolumn{2}{c}{ Winter 1901/1975 } & Total 2 & Ratio \\
& Dec. & Jan. & Feb. & & Dec. & Jan. & Feb. & & Total 1/ Total 2 \\
\hline Gibárt & 58 & 70 & 60 & 188 & 35 & 23 & 24 & 82 & 2.29 \\
Hidasnémeti & 85 & 81 & 71 & 237 & 39 & 28 & 29 & 96 & 2.47 \\
Vilmány & 79 & 73 & 69 & 221 & 46 & 28 & 28 & 102 & 2.17 \\
Szikszó & 97 & 78 & 62 & 237 & 38 & 26 & 26 & 90 & 2.63 \\
\hline
\end{tabular}

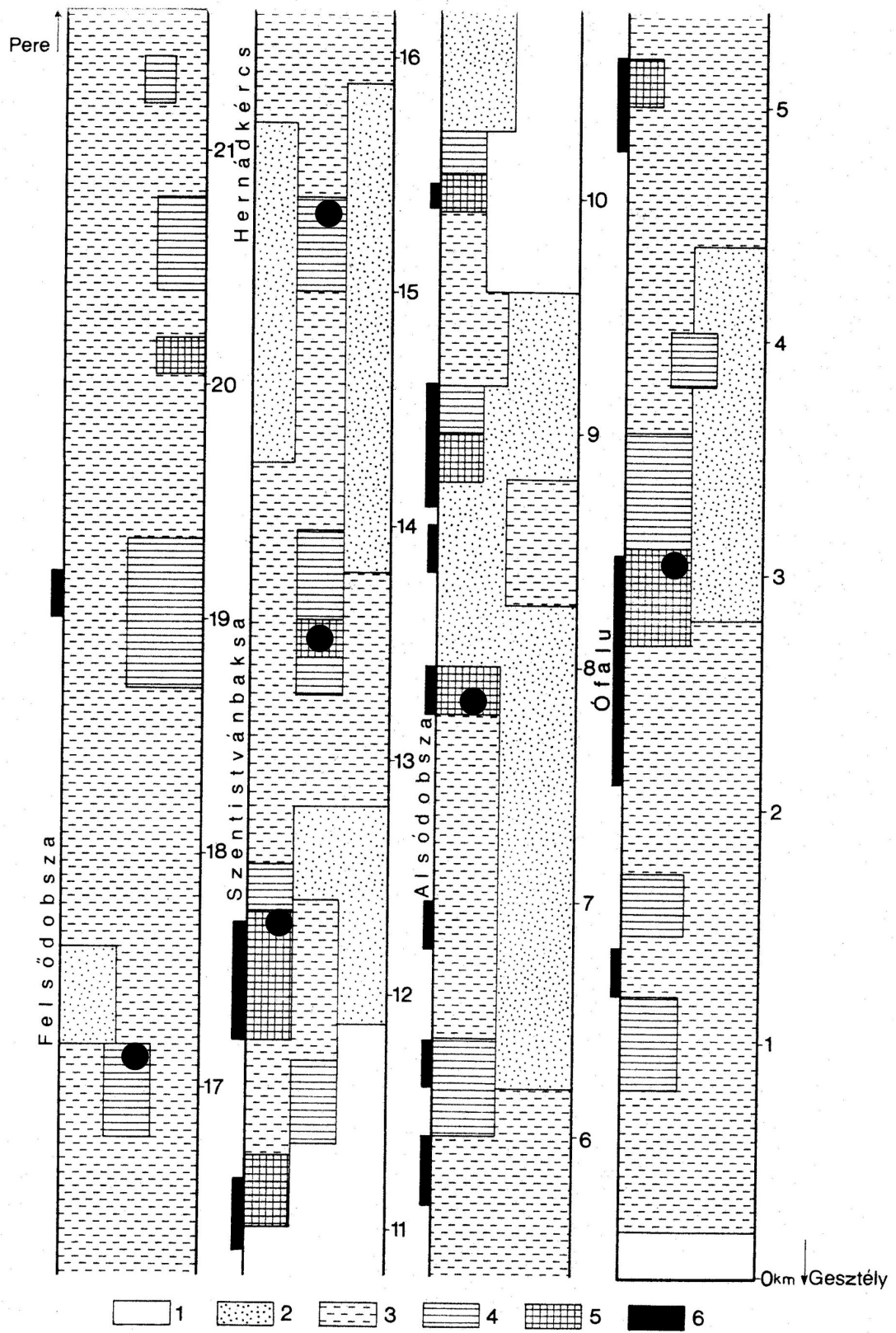

Fig. 4. Activity grades of slope evolution through sliding on the left bank of the Hernád between Pere and Gesztely (0-22 km) The toe of the bank is on the left side of the band chart. $1=$ slopes without landslide features (grade 0 ); 2 = bank section with heavily degraded features (grade I); 3 = slope segments with recent slide forms, now at rest (grade II); 4 = recently unstable slope with active segments (grade III); 5 = slope segment dominated by active slides (grade IV); $6=$ river undercutting of bluff (black dots show the new and renewed landslides in spring 1977.). 


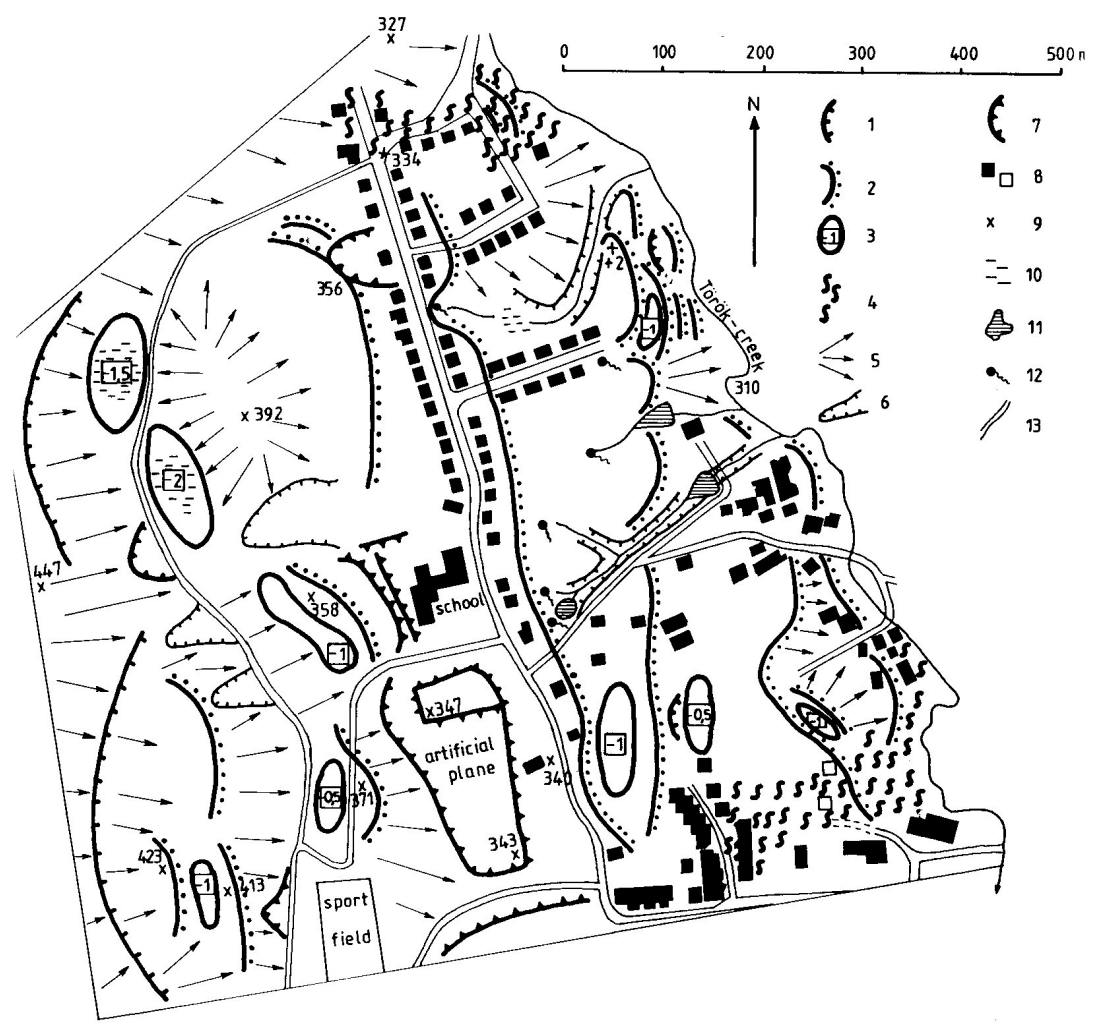

Fig. 5. Geomorphological map of the midwestern part of the village Hollóháza with landslide features $1=$ free face of landslides, $2=$ margins of landslide steps, 3 = closed depressions of landslides (depth in metres), $4=$ unstable surfaces (active movements between 1999-2000), $5=$ main slope directions, $6=$ erosional valleys, $7=$ artificial walls, scarps, $8=$ buildings (empty quadrilateral $=$ demolished building) groundplan of buildings approximate, $9=$ height points, $10=$ waterlogged depressions, $11=$ artificial lakes, $12=$ springs, $13=$ roads, streets. The empty (white) sections are almost flat or slightly undulating surfaces.

on the geomorphological map showing the mid-western part of the settlement (Fig. 5). Although the risk of movement was indicated by the landslide inventory, the drier weather conditions of recent decades - especially the aridity of the nineties - made the population incautious and several houses were built on the flat surfaces of stepped landslides (Szabó, 2000).

\subsubsection{Landsliding and precipitation}

Annual mean precipitation between 1990-1997 (575 mm) was almost $10 \%$ below the average of many years (Table 4 ). A considerable precipitation surplus was measured in the autumn of 1998 and the last month of the winter (February 1999) brought an absolute record $(76 \mathrm{~mm})$ since the beginning of precipitation measurements (1901). Most of the movements took place in March (1999) but after a temporary dormancy, they resumed activity in the middle of the summer (1999) and with a smaller intensity at the beginning of 2000. Twenty-two houses were strongly damaged in the settlement and 70 were severely endangered. The damage and the costs of protection measures amounted to USD 200000 to 300000 .

The case of Hollóháza does not only indicate the close relationship between landslides and winter precipitation, but
Table 4. Representative precipitation data for Hollóháza (mm) (station Füzérkomlós $/ 220 \mathrm{~m}$ a.s.1./ is at ca. $3-5 \mathrm{~km}$ from the landslideaffected areas)

\begin{tabular}{ccccc}
\hline Period & Year & Autumn & Winter & February \\
\hline $1901-1975$ & 632 & 149 & 100 & 30 \\
$1975-1989$ & 633 & 127 & 107 & 28 \\
$1990-1999$ & 602 & 166 & 84 & 31 \\
1998 & 778 & 234 & $61^{*}$ & $3^{* *}$ \\
1999 & 647 & 116 & 120 & 76 \\
\hline
\end{tabular}

$* 1997 / 1998, * * 1998$

it also allows for another conclusion. In Hungary - in the light of the flood disasters of the past years (record floods along the Tisza in 1998, 1999, 2000 and 2001) - it has to be emphasised even more clearly that the gentle decrease in the amount of precipitation of the past decade did not reduce the extreme fluctuations in precipitation. Thus, the deriving risks have to be taken into account, both from the aspect of the floods and the landslides. 


\section{Final remarks}

It may be claimed on the basis of the decades of research carried out by the author in the field of landsliding that the formation of mass movements in the Hungarian landscapes with recent and active landslides may be connected primarily to the irregular recurring and unusually wet periods under moderate continental climate susceptible to drought. The risk is highest after winters with abundant precipitation, when landslides become active again in all three types of landscapes susceptible to landsliding. Even a single wet winter month brings about a rise in landslide activity. Rainy autumns (October 1975 in the Hernád Valley and the autumn of 1998 at Hollóháza) may lead to landslides occurring at the end of winter or in spring. Experience shows that individual (short but intense) rainfalls - typical of summer weather in Hungary - rarely cause a large-scale renewal of landsliding. The largescale temporal discontinuity of landsliding increases the hazard because the periods of tranquillity often result in the intensification of economic activities on the areas of dormant landslides.

The findings of research in Hungary harmonise with the relationships between landslide activity and the fluctuation of precipitation pointed out in other areas. A close correlation was found, for instance, by Crozier (1984) between the hundred-year (1880-1980) annual and monthly maximum precipitations for Wellington, New Zealand, on the one hand, and major landslide damage, on the other. In the environs of Durban, South Africa, Olivier et al. (1993) analysed a twenty-year interval (1970-1990) and revealed a strong relationship between three-day and monthly precipitation, on the one hand, and the annual frequency of landslides, on the other. Benitez (1989) showed a clear coincidence of annual precipitation at Quayaquil, Ecuador, with the landslide disasters in the western part of the country between 1947 and 1987. The above observations are particularly well confirmed by the findings of Corominas and Moya (1996), who studied rainfall patterns in the Eastern Pyrenees and found that high intensity, short duration rainfall events trigger mostly debris flows and shallow slides, while moderate intensity rains induce or reactivate mudslides, and rotational and translational movements. The latter result is in particularly good accordance with the situation in Hungary.

According to one of the most probable scenarios of the global climate changes, the climate of Hungary may become drier but its Mediterranean features may intensify. One of the predicted consequences is an increase in winter precipitation. On the other hand, it does not exclude extreme rainfall events and landslide risk may increase.

Acknowledgements. The author thanks for the support of National Scientific Research Fund (OTKA - 14948) and of Ministry of Education (FKFP 0504/1997 and 0499/2000).

\section{References}

Benitez, S. A.: Landslides: Extent and economic significance in Ecuador, In: Landslides: Extent and Economic Significance, (Eds) Brabb, E. E., Harrod, B. L., Balkema, A. A., Rotterdam/Brookfield, 123-127, 1989.

Corominas, J. and Moya, J.: Historical landslides in the Eastern Pyrenees and their relation to rainy event, In: Landslides, (Eds) Chacon, Irigaray-Fernández, Balkema, A. A., Rotterdam/Brookfield, 125-132, 1996.

Crozier, M. J.: Techniques for the morphometric analysis of landslips, Zeitschrift für Geomorphologie, 78-101, 1973.

Crozier, M. J.: Field Assesment of Slope Instability, In: Slope Instability, (Eds) Brunsden, D., Prior, D., John Wiley and Sons, 103-142, 1984.

Hansen, M. J.: Strategies for Classification of Landslides, In: Slope Instability, (Eds) Brunsden, D. and Prior, D., John Wiley and Sons, 1-26, 1984.

Horváth, Zs. and Scheuer, Gy.: A dunaföldvári partrogyás mérnökgeológiai vizsgálata (Engineering-geological investigation of the river bank slide of Dunaföldvár), Földtani Közlöny, 106/4, 425-440, 1976.

Hutchinson, J. N.: Mass movement, In: The Encyclopedia of Geomorphology, (Ed) Fairbridge, R. W., Reinhold Book Corporation, 688-695, 1968.

Juhász, Á.: A klimatikus hatások szerepe a magaspartok fejlod'esében (The role climatic effects in the development of high embankments), Földtani Kutatás, XXXVI/3, 14-20, 1999.

Juhász, Á. and Schweitzer, F.: A Balatonkenese és Balatonvilágos közötti magaspartok felszinmozgásos formatipusai (Landslide types on high banks between Balatonkenese and Balatonvilágos), Földrajzi Értesito, XXXVIII, 305-318, 1989.

Lóczy, D., Balogh, J., and Ringer, Á.: Landslide hazard induced by river undercutting along the Danube, Supp. Geogr. Fis. Dinam. Quat., II, 5-11, 1989.

Olivier, M., Garland, G., and Jermy, C.: Rainfall-landslide relationships in Durban - a preliminary assessment, Geoökodynamik, Band XIV, 85-92, 1993.

Pécsi, M., Schweitzer, F., and Scheuer, Gy.: Landslide control at Dunaújváros, In: Hillslope experiments and geomorphological problems of high river banks, Guide, Budapest, MTA-FKI, (Theory-Methodology-Practice 43), 93-98, 1993.

Pécsi, M.: A landslide type occurring frequently along the loess bluff in the Hungarian Danube section, Quaternary International, 24, 31-33, 1994.

Pécsi, M., Juhász, Á., and Schweitzer, F.: Mapping areas of unstable surface in Hungary, In: International Conference on Geomorphological Mapping, Geogr Res. Inst. Hung. Acad Sci., Budapest, 152-166, 1978.

Simonett, D. S.: Landslides, In: The Encyclopedia of Geomorphology, (Ed) Fairbridge, R. W., Reinhold Book Corporation, 639641, 1968.

Szabó, J.: Landslide processes and forms in the Hungarian mountains of volcanic origin, In: New perspectives in Hungarian Geography, (Eds) Kertész, 'A. and Kovács, Z., Budapest, 63-75, 1992.

Szabó, J.: Vergleichende Untersuchungen der Rutschnungprozesse in Ungarn, Berliner Geographische Arbeiten, Heft 79, Berlin, 133-161, 1993.

Szabó, J.: Csuszamlásos folyamatok szerepe a magyarországi tájak geomorfológiai fejlodésében (The role of landslides in the geomorphological evolution of Hungarian landscapes), Kossuth 
Egyetemi Kiadó, Debrecen, 223, 1996a.

Szabó, J.: Results and problems of cadastral survey of slides in Hungary, In: Landslides, (Eds) Chacon, Irigaray and Fernandez, Balkema, A. A., Rotterdam/Brookfield, 71-78, 1996b.

Szabó, J. and Félegyházi, E.: Problems of landslide chronology in the Mátra mountains in Hungary, Eiszeitalter und Gegenwart, Hannover, 47, 120-128, 1997.
Szabó, J.: Problems of reactivated landslides, In: Anthropogenic aspects of landscape transformations, (Eds) Lóki, J. and Szabó, J., Debrecen, 68-76, 2000.

Zelenka, T. and Trauer, N.: A hollóházai földmozgások földtani okai (Geological reasons of landslides in Hollóháza), Földtani Kutatás XXXVI./3, 27-33, 1999. 